\title{
After the Ali Enterprises Fire: Occupational Safety and Health and Workers' Organising-A Conversation with Zehra Khan About Current and Future Struggles
}

\author{
Palvasha Shahab
}

\begin{abstract}
Zehra Khan is a prominent labour activist and journalist who has been working in Karachi, Pakistan, for more than a decade. She is the founder and General Secretary of the Home Based Women Workers Federation of Pakistan (HBWWF). She also works closely with the National Trade Union Federation (NTUF). In this interview, she speaks to Palvasha Shahab about current and future struggles in regards to working conditions in Pakistan.
\end{abstract}

Keywords Collective organising $\cdot$ Labour movement $\cdot$ Workers struggle $\cdot$ Ali Enterprises factory fire $\cdot \mathrm{KiK}$ case

Zehra Khan is a prominent activist and seasoned journalist who has been working in Karachi, Pakistan, for more than a decade. She is the founder and general secretary of the Home Based Women Workers Federation of Pakistan (HBWWF). She has also been a steadfast supporter of and close collaborator with Pakistan's National Trade Union Federation (NTUF), and a vocal ally of the families affected by the 2012 Ali Enterprises factory fire. Her voice has been an important part of the struggle for justice in the aftermath of the Ali Enterprises fire.

Palvasha Shahab: What is your recollection of the day of the Ali Enterprises fire?

Zehra Khan: I was at the NTUF office that day and was on my way home when I heard the news. When I reached home and watched the whole news on TV, I saw it was a terribly aggressive fire. News of the factory fire was aired on TV continuously for 3 days. I heard on Geo News that more than 300 workers had died in the fire incident. ${ }^{1}$

\footnotetext{
${ }^{1}$ Although the initial news reports cited higher numbers, the total number of deaths was later determined to be 255, established by the Judicial Commission that conducted thorough

P. Shahab $(\bowtie)$

Rasheed Razvi Centre for Constitutional and Human Rights (RCCHR), and the Legal Aid

Foundation for Victims of Rape and Sexual Assault (LAFRSA), Karachi, Pakistan

e-mail: palvasha.shahab@columbia.edu 
The next morning, I arrived at the scene of the fire and there was destruction everywhere. Later that day, we held a protest at the Karachi Press Club. The fire just kept raging and bodies just kept emerging. When we returned to the factory to continue our protest there, we saw that MQM [Muttahida Qaumi Movement, a political party with considerable clout in the area at the time] had organised a vigil, where they were lighting candles and mourning the dead. I walked past the crowd of people that had collected for our protest, past the MQM vigil and the families of those affected. When I got past them, I saw that EOBI [Employees' Old-Age Benefits Institution] had set up their desk and, as bodies were being retrieved from the fire, they were registering dead bodies. They were actually registering workers posthumously for the benefits scheme!

That day, I also crossed the police lines that cordoned off the fire stricken factory, and found some burnt jeans that had the KiK label on them. At the time, I did not know what it was, but I later learnt that it was a German retail brand. One of the photographs that I took was circulated across the internet and news media. I later found out that the factory predominantly manufactured semi-finished and finished products for "OKAY Jeans" for KiK, which is based in Germany. Also later, in my interviews with workers, I found out that the factory employed approximately 2000 workers in different shifts for different jobs, and that a small portion of its production was also for other brands like Go Blue and Diesel.

Shahab: How did you become involved in the longer-term response to the Ali Enterprises Factory Fire?

Khan: A lot of things happened simultaneously. As I mentioned, the very next day, we were at the Karachi Press Club, along with our trade union affiliates, and were protesting under the slogan: "Safety first, the workplace should be safe for all workers!" After the fire, we organised regular meetings with trade unions and especially with home-based women workers, and we mobilised them around safety issues and said that the workplaces will not be safe until there is a big movement. We contacted almost all trade unions, as well as representatives of political parties, civil society, and human rights organisations. We also mobilised workers outside the courts, such as when the [Ali Enterprises] factory owners' bail application was being heard.

Then, on the other hand, in the months following the fire, the Pakistan Institute for Labour Education and Research (PILER) ${ }^{2}$ was involved in negotiations with the international brand [KiK]. Near the end of 2012, they settled on immediate relief of US\$1 million and the promise of future compensation. However, at the time, we only heard that a local organisation was negotiating with the brand and guessed that it was

investigations, including DNA tests. Report of the Judicial Commission on Baldia Factory Fire Incident, Karachi, 28 August 2013, Court File of Constitutional Petition 3318 of 2012, p. 1379. For earlier reports, please see: Death Toll from Karachi Factory Fire Soars, BBCNews.com, 12 September 2012 www.bbc.com/news/world-asia-19566851 (last accessed 23 September 2020).

${ }^{2} \mathrm{~A}$ prominent labour rights organisation in Pakistan. 
PILER, because most of us were unaware that this was happening. But later, the workers, NTUF, IndustriALL, ${ }^{3}$ and the Clean Clothes Campaign, etc. were also involved in the following rounds of negotiation. ${ }^{4}$ In early 2013, on behalf of NTUF, I also conducted an initial survey on the fire tragedy. For the survey, I interviewed more than 100 affected families and connected with even more victims' families.

Shahab: How were you involved with the forming of the Ali Enterprises Factory Fire Affectees Association (AEFFAA)?

Khan: Even though we had initially met quite a few affectees in the immediate aftermath of the fire and interviewed them, it was only after we began working with a different, more consistent group of affectees that things picked up steam. About a year and a half after the fire, we met a group of affectees outside the old NTUF office in the Mashriq Centre. When we ran into them, in the building, it turned out that Nasir Mansoor of NTUF knew some of them. That was the group that took the initiative to keep fighting for justice and keep encouraging other affectees to keep fighting; from then onwards that was the group we collaborated with. Upon our [Nasir Mansoor and Zehra Khan] suggestion, they formed the association [the Ali Enterprises Factory Fire Affectees Association (AEFFAA)] almost a year and a half after the fire. So as a result, together with NTUF, I helped the victims and affected families come together in the form of an association and we have been working together ever since.

Shahab: How would you describe the formation of the coalition between the national and international actors? What role did the case in Germany against KiK play in this?

Khan: On the international front, first Nasir Mansoor contacted IndustriALL, with whom NTUF is affiliated. Later the European Center for Constitutional and Human Rights (ECCHR) and the Clean Clothes Campaign (CCC) joined, and so forth, as time went by. When ECCHR wanted to file a case in Germany, we supported that idea. PILER and the lawyer Faisal Siddiqi initially thought it was risky and wanted to pursue litigation in the courts here [in Pakistan] instead. They said that KiK had already promised a second round of negotiations and more compensation, so we should pursue that and focus on the litigation here in Pakistan. They believed it could jeopardise the negotiations which were being facilitated by the International Labour Organization and, if it failed on substantive grounds, it could set an unfavourable legal precedent. Then, when negotiations with KiK hit a roadblock, PILER and Faisal Siddiqi also extended their support to the litigation in Germany in the hope that Kik may be pressurised into returning to the negotiating table.

We, as HBWWF and NTUF, supported and facilitated the idea of litigating abroad from the very beginning. When ECCHR came to Pakistan and discussed this idea with us, we gathered a group of affectees, assisted in the selection of

\footnotetext{
${ }^{3}$ An international labour union.

${ }^{4}$ As described in the chapters by Faisal Siddiqi and Miriam Saage-Maaß in this volume.
} 
petitioners or plaintiffs, and then helped the Petitioners sign their Powers of Attorney and get their other documents in order. The documentation process was also riddled with difficulties and we ended up repeating the process a few times before everything was in order for filing. We also helped get the necessary expert opinions from Pakistan that could be used for the litigation in Europe.

Shahab: What are the results of the different legal struggles in Pakistan and Germany?

Khan: Regardless of the results of the court case, ECCHR has really managed to keep the issue alive in Europe. The media and lawyers, in general, have really managed to keep this issue alive, both here and in Europe. For the litigation in Pakistan, the results were compensation-oriented. There [in Germany], our main objectives were to create an opportunity for ensuring worker safety while also ensuring that people affected by the fire were involved and included in all decisions being made on their account, such as negotiations, litigation, pensions, compensation, and so forth.

In the end, a Compensation [Judicial] Commission was set up for the distribution of compensation that was being provided by the Government of Sindh, the Federal Government, and through the initial instalment from KiK. The commission was headed by a retired judge and was formed through an order of the High Court of Sindh (SHC). The Compensation [Judicial] Commission distributed compensation money in two rounds. The criteria set up by this commission was also used to administer the ILO pensions that came a few years later in 2018. The Government of Sindh distributed 300,000 Pakistani rupees to the family of each deceased person and 50,000 Pakistani rupees to each injured person. The federal government gave 400,000 Pakistani rupees to the family of each deceased person. The Compensation [Judicial] Commission also prepared criteria for distributing compensation amongst different legal heirs from the same family. This was important because, initially, the male members of the family were keeping all the money, and women, particularly those who had been widowed in the fire, were not being given any share.

In the first round, legal heirs of each deceased worker received a total amount of 500,000 Pakistani rupees. Whereas in the second round, the same legal heirs of each deceased worker will receive a total of 110,000 Pakistani rupees. This commission also distributed compensation money among 55 injured workers. For the injured workers, the commission formed the following criteria to distribute compensation:

Permanently disabled injured workers: 500,000 Pakistani rupees

Gravely injured workers: 250,000 Pakistani rupees

Simply injured workers: 125,000 Pakistani rupees

Shahab: You conducted a study on the Ali Enterprises fire incident on behalf of NTUF in 2013. Could you please elaborate on your findings from this study?

Khan: The survey was very revealing. First, the workers who were interviewed confirmed that the emergency gates were locked on the instruction of the factory management. All windows were blocked permanently with iron grills on the pretext of stopping the theft of merchandise. It was horrifying. It was also the result of 
criminal negligence. Second, it was also found that this fire incident was not the first in the factory. Two fire accidents had occurred in the same factory earlier in the year, in February and September 2012, respectively. Only, those fires were not as dreadful as this mishap. They had both been caused by electric short-circuiting. Third, both before and after the previous two smaller fires, the factory owners did not take any precautionary measures to secure their workers' lives. The factory management had not even so much as ensured a functional emergency fire alarm or smoke detector alarms to alert the workers to a fire or other emergency so that they could escape during such situations to save their lives. Fourth, the workers didn't have any training or support to cope with emergency situations. Fifth, there was only one entrance and exit point, which was also blocked with materials and merchandise dumped here and there. The three-story garment factory had only one exit and no functioning firefighting equipment. Sixth, it was also revealed, by some surviving workers that, among the workers hired through contractors, children also used to work in Ali Enterprises Factory without any medical clearance as mandated by the Factories Act, 1934. Seventh, the Labour and Human Resources Department of the Government of Sindh also confirmed that Ali Enterprises was not officially registered with them, and its building design was also not approved by the competent Building Control Authority. The factory had been functioning for years in the heart of an industrial zone in Karachi, illegally, without any check. Eighth, hardly any workers had social security, as the majority of the workers didn't have formal appointment letters and most of them were hired through third-party contractors. When workers do not have appointment letters, it is very easy to deny the workers any kind of job security, entitlement to sick leave, health cards, compensation for injury at the workplace, registration with social security schemes, and so forth. The same tactic of recruiting through contactors is adopted by the majority of employers in Pakistani factories, to avoid abiding by the rights guaranteed to workers. This makes workers even more vulnerable to excessive working hours and extremely, even fatally, unsafe conditions.

Shahab: As you report, there has been quite some compensation paid to the victim's families and the surviving workers. What are the issues remaining?

Khan: Firstly, the conditions of workplace safety have not improved and there is still complete impunity for violating safety laws. Moreover, precarious employment continues to be the norm. Workers are hired through third party contractors; they are denied employment letters and denied registration with the Sindh Employees Social Security Institution, EOBI and the Workers Welfare Fund. As a result, they have no safety at the workplace, no job security and no health and pension benefits. Forget informal workplaces, discreet sweatshops and home based workers - even formally registered factories are not following safety laws, rules, regulations, standards or best practices.

Secondly, it is very unfortunate that in an industrial city like Karachi, where more than $65 \%$ of the country's revenue is generated, there was no laboratory to conduct DNA tests at the time when the Ali Enterprises fire happened. There was no proper mechanism to collect the DNA samples of the deceased's blood relatives. As a result, the bereaved families endured agony and trauma for many months to get the DNA reports to confirm the identity of unclaimed, unrecognisable bodies lying in the Edhi 
mortuary of Karachi. A year after the fire, there were still 25 unidentified workers, and 17 of them were buried in the Baldia graveyard of the city. After the fire incident, many workers became unemployed and many of those who were injured due to the fire didn't get proper treatment from the government. Now these families are still facing problems and struggling to make ends meet. The lack of systems and streamlined processes which are responsive to the realities on ground is often the undoing of the working class in particular and of the citizens of Karachi in general.

Thirdly, even more importantly, we found that many of the workers who were employed at the factory were of Bengali or Bihari ethnicity (who are frequently undocumented, and were so in these cases too), and their applications for documentation had either been denied or they had never attempted to make national identity cards (because of the general community-wide belief that their application for national identitiy cards would be denied). Some of them did not even have birth certificates. Later, as the Prime Minister Raja Parvez Ashraf, the Sindh government, and other entities like $\mathrm{KiK}$ were announcing compensation, these workers or their families could not access that money because they did not have the requisite identification documents and, hence, also did not have bank accounts. So, we had to try to help them or their families get some kind of documentation or see how they could be paid without bank accounts and documentation - such as in cash. At present, I believe five of the pensions are being given in cash.

Shahab: How do you assess the role of international companies in the Ali Enterprises incident?

Khan: The catastrophic incident itself, and all the investigations and reporting that followed, revealed that not only local manufacturers, but also international companies, brands, and audit certification organisations (such as Social Accountability International, which issues the SA-8000 certificates), are all responsible for the prevailing situation of workers' rights; the poor safety standards at workplaces, and the grievous or fatal accidents and diseases that result from these conditions. International brands and audit certification organisations should implement the international labour standards for safeguarding the rights of workers in producing countries like Pakistan, but sadly, they become the key drivers of exploitative global value chains and local private enterprises become vehicles of this oppressive chain whose participants just want money by hook or by crook.

These multinational companies don't pay any attention to the inhuman working conditions prevailing in workplaces like Ali Enterprises, which provide the products they then sell in European and North American markets. They fully know about the working conditions in Pakistani factories. They are aware that laws are not followed and that genuine unions, that can possibly safeguard the workers and work towards securing their rights, are not allowed to exist, and they benefit from it. The international brand $\mathrm{KiK}$ belatedly and only indirectly assumed responsibility for the fire when they agreed to pay compensation - and only after intense pressure from various international and domestic organisations. The factories supplying merchandise, as well as the international brands and retailers, are morally and ethically bound. They should all be legally bound with the threat of liability, to enforce national and international labour standards, as they miserably fail to fulfil their so-called corporate responsibilities. 
Shahab: You are heavily involved with home-based workers. What proportion of them are textile and garment workers and what are the difficulties, safety concerns, wage theft or other problems faced by home-based workers? How are these different from the problems of those working in formal factories?

Khan: There are approximately 12 million home-based workers in Pakistan, out of which 3-4 million are living in the province of Sindh. About 60\% of home-based workers are engaged with the textile and garment sector, including in stitching, cropping, packing, folding, sorting, patchwork, embroidery, elastic work, buttonmaking, beadwork, etc. And approximately $80 \%$ are female workers who work at very cheap rates and uses their home as their workplace. They get work from different contractors and middlemen, without knowing for whom, for which market, and for which brand they are working. Their actual employers are veiled and obscured, due to which they can't get any benefits within the existing legal structure.

Home-based workers are not protected by labour laws in Pakistan. They are not allowed to form unions, their minimum wages are not fixed by law, they are working for very low wages without any social benefits, their jobs are not permanent, and they have no job security. As their terms and conditions of employment are not certain, they end up working long hours and having to invest in and use their own work material and infrastructure, such as sewing machines, electricity, etc. All these things make them even more vulnerable. They have no benefits, despite the fact that they are an important part of the supply chain.

Nevertheless, due to our efforts, Sindh became the first province to recognise and empower home-based workers. The Sindh Home Based Workers Act of 2018 was passed in Sindh on 9 May 2019 by the Sindh Assembly. ${ }^{5}$ The minimum wage board has now included home-based bangle workers in their minimum wage gazette for the first time. Moreover, official rules were also formulated under the act and were notified in January 2020. We are hopeful that home-based workers' registration will start with the Labour and Human Resources Department of the Government of Sindh in August 2020.

Shahab: How do you place the tragic fire in the context of the labour struggles in Pakistan?

Khan: The Ali Enterprises factory fire was an emergency siren for worker safety in Pakistan. The incident has changed into a new symbol of workers' resistance, which could eventually help factory workers to secure the right of having a decent working environment and to get rid of social injustice and prevailing modern slavery based on crony capitalism.

The accident forced the government to confront the miserable working conditions in factories and workplaces, or rather, the fire slapped the government in the face

\footnotetext{
${ }^{5}$ See Yousafzai A, 11-year struggle for home-based workers' rights set to bear fruit this year. The News, 18 January 2019, www.thenews.com.pk/print/420315-11-year-struggle-for-home-basedworkers-rights-set-to-bear-fruit-this-year\#: :text=After\%20many $\% 20$ years $\% 20$ of $\% 20$ efforts, their $\% 20$ status\%2C\%E2\%80\%9D\%20Khan\%20said (last accessed 10 September 2020).
} 
with these miserable work conditions. For instance, the government introduced a number of initiatives to improve overall working conditions in factories and workplaces. One of these initiatives is an ILO-supported project on occupational safety and health (OSH). Another is the Deutsche Gesellschaft für Internationale Zusammenarbeit (GIZ) pilot project in the Punjab province to improve the working environment through a tripartite mechanism in 10 selected factories. This initiative is also to be extended to Karachi in the near future. The Sindh government has also initiated a number of measures in response to workers' demands, including OSH legislation [The Sindh Occupational Safety and Health Act, 2017], and has declared 11 September as "Health and Safety Day" in the province.

In the years following the fire, the Government of Sindh has finally recognised agricultural labour, including cotton field workers, as workers protected by labour law, and is now more willing to explore ways to extend legal rights and social and economic protections to them. The Government of Sindh also recognises homebased workers as workers who are an integral part of ready-made-garment-sector supply chains.

Shahab: What are the struggles for workers' unions lying ahead?

Khan: Occupational safety and health remains one of the main issues for the workers. Five years after the Ali Enterprises incident, a law, that is, the Sindh Occupational Safety and Health Act, 2017, was passed in Sindh. Now, 3 years later, the implementation of this act is still far away. Pakistan has still not implemented most of the international conventions on OSH that it has signed and ratified. ${ }^{6}$ The importance of occupational safety and health hasn't been understood by government departments and employers. Therefore, many factories are still death traps for workers.

Factories are unsafe for workers. Workers' access to the right to freedom of association is still a dream. One of the most dangerous and most common characteristics of textile and garment establishments, especially the units which produce merchandise for international brands, is that the management of these factories often form two or more "yellow" labour unions, ${ }^{7}$ with acquiescence from the officials from the Labour and Human Resources Department, to block workers from forming genuine, representative, independent unions. These factories engage in this illegal labour practice to gain superficial credibility or to fulfil the requirements needed to attract orders from international buyers, ${ }^{8}$ and these international buyers usually know exactly what is going on. In the meanwhile, many of the workers in the

\footnotetext{
${ }^{6}$ Pakistan has signed and ratified various ILO conventions on labour administration and inspections, occupational safety and health, social security, working times, and various other issues. Details can be found at: Ratifications for Pakistan, ILO, Normlex www.ilo.org/dyn/normlex/en/f? $\mathrm{p}=$ NORMLEXPUB:11200:0::NO::P11200_INSTRUMENT_SORT,P11200_COUNTRY_ ID:2,103166\#Occupational_safety_and_health (last accessed 10 September 2020).

${ }^{7} \mathrm{~A}$ "yellow" union is a worker organisation that is dominated or influenced by an employer and is therefore not an independent trade union.

${ }^{8}$ Many transnational corporations have requirements under voluntary corporate social responsibility mechanisms, codes of conduct, or other similar documents. For more details, see the chapter by Michael Bader in this book.
} 
factories often don't even know about the existence of the fake "yellow" unions that are apparently representing them.

Every factory must have a genuine union and the right of collective bargaining, so a constructive dialogue between employers and workers can be started and both parties can mutually understand each other and reach an agreement on working conditions in which every worker can feel safe during work. This environment would also support employers in increasing their work. But unfortunately, in Pakistan, employers are still involved in making dummy unions, where there is no collective bargaining.

Palvasha Shahab was the joint executive director of the Rasheed Razvi Centre for Constitutional and Human Rights, and the Legal Aid Foundation for Victims of Rape and Sexual Assault through September 2020. She now works a consultant for RCCHR, LAFRSA, the Legal Aid Society and the Pakistan Institute for Labour Education and Research. She is on the Law Committee of the Sindh Commission of the Status on Women and advises on upcoming legislation. She is also an advisor to a transnational collaborative project on oral histories and social interventions titled "Karachi Beach Radio." She also teaches undergraduate courses on peace movements and international human rights law at SZABIST, Karachi. Shahab further curates and moderates important public discussions on national platforms such as the Adab Fest and The Second Floor. She holds a Master of Laws from Columbia Law School, New York, US, where she was also a Human Rights Fellow at the Human Rights Institute in 2017-2018.

Open Access This chapter is licensed under the terms of the Creative Commons Attribution 4.0 International License (http://creativecommons.org/licenses/by/4.0/), which permits use, sharing, adaptation, distribution and reproduction in any medium or format, as long as you give appropriate credit to the original author(s) and the source, provide a link to the Creative Commons license and indicate if changes were made.

The images or other third party material in this chapter are included in the chapter's Creative Commons license, unless indicated otherwise in a credit line to the material. If material is not included in the chapter's Creative Commons license and your intended use is not permitted by statutory regulation or exceeds the permitted use, you will need to obtain permission directly from the copyright holder.

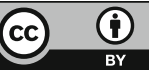

